\title{
PENGARUH PELATIHAN TERHADAP KETERAMPILAN PRAMUSAJI FOOD AND BEVERAGE SERVICE DI HOTEL SWISS-BELINN MALANG
}

\author{
Karina Rizka Mentari ${ }^{1}$, Darmawan Ockto $\mathbf{S}^{2}$, A. Faidlal Rahman ${ }^{3 *}$ \\ ${ }^{1,2,3}$ Program Studi Manajemen Perhotelan, PendidikanVokasi, Universitas Brawijaya \\ Jl. Veteran 12-16, Kota Malang, Indonesia \\ E-mail: 'karinarizka21@gmail.com; ${ }^{2}$ darmawanockto@gmail.com; ${ }^{3}$ faidrahman@ub.ac.id \\ *Penulis korespondensi
}

\begin{abstract}
Abstrak
Penelitian ini bertujuan untuk (1) mengetahui dan menganalisis pengaruh variabel pelatihan terhadap keterampilan pramusaji secara simultan, (2) mengetahui dan menganalisis pengaruh variabel pelatihan terhadap keterampilan pramusaji secara parsial, (3) mengetahui dan menganalisis variabel pelatihan yang paling berpengaruh terhadap keterampilan pramusaji. Jenis penelitian yang digunakan adalah Explanatory dengan menggunakan kuisioner sebagai alat pengumpul data yang disebarkan kepada responden dengan sampel sebanyak 15 karyawan pramusaji. Teknik pengambilan sampelnya menggunakan Sampling Jenuh. Hasil penelitian menunjukkan bahwa variabel pelatihan yang terdiri dari Pelatih Pelatihan (X1), Peserta Pelatihan (X2), Materi Pelatihan (X3), Metode Pelatihan (X4), Tujuan dan Sasaran (X5) secara simultan dan parsial berpengaruh terhadap Keterampilan Pramusaji (Y). Variabel Materi Pelatihan (X3) memiliki pengaruh dominan terhadap keterampilan pramusaji (Y).
\end{abstract}

Kata kunci: Pelatihan, Keterampilan Pramusaji, Hotel.

\begin{abstract}
This research intent to purpose (1) know and analyze the influence of training variables on the skill of the waiter simultaneously, (2) to know and analyze the effect of training variables on the skill of the waiter partially, (3) to know and analyze the most influential training variables on the waiter's skill. The type of research used is Explanatory by using questionnaires as a means of collecting data distributed to the respondent with a sample of 15 employees waitress. The sampling technique uses Sampling Jenuh. The results showed that training variables consisting of Training Instructur (X1), Training Participants (X2), Training Materials (X3), Training Methods (X4), Goal and Target Training (X5) simultaneously and partially influenced Waiters Skills (Y). Variable Training Material (X3) has a dominant influence on the skill of waiter (Y).
\end{abstract}

Keywords: Training, Waiters Skill, Hotel.

\section{ENDAHULUAN}

Kota Malang merupakan salah satu kota tujuan wisata di Jawa Timur. Salah satu penunjang kegiatan pariwisata di Malang adalah keberadaan industri hotel. Hotel adalah suatu usaha yang bergerak di bidang akomodasi yang dikelola secara profesional guna menghasilkan keuntungan dengan menyediakan pelayanan penginapan, makanan, minuman, dan fasilitas yang lainnya (Utama, 2016:43). Jumlah hotel yang ada di Malang pada tahun 2015 sebanyak 104 hotel dan terdapat 4.324 kamar dari hotel tersebut (BPS Kota Malang, 2016). Tingkat hunian kamar yang terjual untuk hotel berbintang sebesar $83,54 \%$ dari total kamar yang dimiliki hotel berbintang dan untuk hotel non bintang sebesar 39,93\% dari total kamar yang dimiliki hotel non bintang. Keberadaan hotel yang semakin banyak menjadikan persaingan hotel menjadi semakin ketat.

Persaingan antar hotel yang semakin ketat memaksa hotel untuk berinovasi dan memberikan pelayanan yang terbaik bagi pelanggan hotel tersebut. Hal tersebut tidak akan berjalan lancar apabila tidak didukung oleh sumber daya manusia yang berkualitas. Sumber daya manusia merupakan hal yang sangat penting dalam suatu perusahaan, karena keberhasilan suatu perusahaan sangat bergantung pada kualitas kinerja sumber daya manusianya. Setiap perusahaan tentunya akan berusaha untuk mendapatkan sumber daya manusia yang hebat dan berkualitas agar dapat mendukung efektivitas dalam pekerjaan dari sebuah perusahaan. Salah satu sumber daya manusia yang berperan penting di sebuah hotel adalah karyawan bagian Food and Beverage Service. 
Hotel Swiss-Belinn Malang merupakan salah satu hotel bintang tiga di Kota Malang. Food and Beverage Service merupakan salah satu departemen di Hotel Swiss-Belinn Malang yang bertanggung jawab untuk menyajikan makanan dan minuman kepada tamu secara profesional dengan tujuan mendapatkan income atau revenue dan profit. Komponen yang tidak bisa terlepas dari bagian Food and Beverage Service adalah pramusaji. Seorang pramusaji akan membawa image perusahaan karena berhadapan langsung dengan tamu dalam memberikan pelayanan makanan dan minuman. Peranan seorang pramusaji sangat besar di dalam organisasi hotel. Salah satu upaya untuk mengembangkan dan meningkatkan keterampilan pramusaji adalah dengan melakukan pelatihan. Fungsi diadakannya pelatihan bagi pramusaji di Hotel SwissBelinn Malang adalah untuk meningkatkan kompetensi kerja yang nantinya diharapkan akan dapat meningkatkan kualitas pelayanan terhadap tamu di hotel tersebut.

Hotel Swiss-Belinn Malang sudah menerapkan pelatihan secara rutin terhadap karyawan khususnya di bagian Food and Beverage Service. Pelatihan dilakukan minimal enam kali dalam sebulan. Pelatihan yang diberikan meliputi product knowledge, hotelier ettiquette, how to pick up food order, welcoming guest, service sequences dan lain sebagainya. Pelatihan service sequences adalah salah satu pelatihan yang harus diberikan kepada pramusaji secara maksimal agar pelayanan yang diberikan selalu konsisten. Pramusaji harus piawai dalam menerapkan service sequences, yaitu etika dan urutan baku pelayanan yang harus diberikan kepada setiap pelanggan.

Walaupun pelatihan service sequence sudah diberikan minimal sekali dalam sebulan oleh perusahaan, akan tetapi karyawan belum menerapkan secara maksimal. Hal ini dibuktikan masih adanya komplain dari pelanggan mengenai pelayanan yang diberikan oleh pramusaji. Beberapa komplain dari tamu adalah tamu kurang puas terhadap pelayanan pramusaji dikarenakan kurang cepatnya pramusaji tersebut dalam memenuhi permintaan tamu, pramusaji tidak menunjukkan sikap yang baik dan ramah kepada tamu, pramusaji tidak dapat menjalankan tugasnya dengan baik, serta pengetahuan mengenai menu-menu restoran kurang dikuasai (Tripadvisor, 2017).

Dari uraian di atas, perlu dilakukan penelitian untuk mengetahui pengaruh pelatihan terhadap keterampilan pramusaji pada hotel Swiss-Belinn Malang. Kinerja pramusaji yang baik dan maksimal akan memberikan kepuasan kepada tamu. Apabila tamu merasa puas akan pelayanan yang diberikan, maka perusahaan memiliki kesempatan untuk membangun loyalitas tamu.

\section{TINJAUAN PUSTAKA}

\section{Pengertian Hotel}

Menurut Utama (2016), hotel adalah suatu usaha yang bergerak di bidang akomodasi yang dikelola secara professional guna menghasilkan keuntungan dengan menyediakan pelayanan penginapan, makanan, minuman, dan fasilitas yang lainnya.

Hotel adalah suatu bentuk bangunan, perusahaan atau badan usaha akomodasi yang menyediakan pelayanan jasa penginapan, penyedia makanan dan minuman serta fasilitas jasa lainnya yang semua pelayanannya diperuntukkan bagi masyarakat umum, baik tamu yang bermalam di hotel ataupun yang hanya menggunakan fasilitas tertentu yang dimiliki hotel tersebut (Larasati, 2016:5).

Jadi dari pengertian di atas dapat disimpulkan bahwa hotel adalah salah satu usaha pariwisata yang bergerak di bidang akomodasi yang menjual jasa penginapan berupa kamar-kamar, makanan dan minuman, dan fasilitas lainnya.

\section{Food and Beverage Departement}

Food and Beverage Departement pada suatu hotel adalah bagian yang menangani pelayanan makanan dan minuman yang dikelola secara komersial dan professional.

Food and Beverage Service terbagi menjadi dua bagian pokok (seksi) yaitu Food Service, seksi yang mengutamakan pelayanan makanan, minuman hanya sebagai pelengkap, yang termasuk dalam kelompok ini adalah restoran, room service, dan banquet. Beverage Service, seksi yang mengutamakan pelayanan minuman (beralkohol) sedangkan makanan dalam bentuk snack hanya sebagai pelengkap, yang termasuk dalam kelompok ini adalah bar, lounge, dan discotheque.

\section{Pelatihan}

Dessler (2016:284), pelatihan (training) adalah proses mengajarkan keterampilan dasar yang dibutuhkan karyawan baru maupun karyawan yang sudah ada untuk melakukan pekerjaannya.

Pelatihan adalah suatu proses yang sistematis dari organisasi untuk mengembangkan keterampilan individu, kemampuan, pengetahuan atau sikap yang dapat merubah perilaku pegawai untuk mencapai tujuan organisasi yang telah ditetapkan (Sinambela, 2016: 170).

Pelatihan merupakan wadah lingkungan bagi karyawan untuk memperoleh atau mempelajari sikap, kemampuan, keahlian, pengetahuan, dan perilaku spesifik yang berkaitan dengan pekerjaan (Punarya, 2016:87). 
Dari pengertian di atas dapat ditarik kesimpulan bahwa pelatihan adalah kegiatan untuk meningkatan kemampuan dan kinerja karyawan dalam melaksanakan tugasnya dengan cara peningkatan keahlian, keterampilan, pengetahuan, dan sikap yang berkaitan dengan pekerjaan.

\section{Keterampilan Pramusaji}

Keterampilan (skills) adalah sama artinya dengan kata kecekatan. Terampil atau kecekatan adalah kepandaian dalam melakukan sesuatu dengan cepat dan benar. Seseorang yang dapat melakukan sesuatu tapi salah tidak dapat di katakan terampil (Soemarjadi, dkk., 2000). Demikian pula dengan seseorang yang melakukan sesuatu dengan benar tapi lambat, juga tidak dapat di katakana terampil. Iverson (2001) mengatakan keterampilan membutuhkan pelatihan dan kemampuan dasar yang dimiliki setiap orang dapat lebih membantu menghasikan sesuatu yang lebih bernilai dengan lebih cepat.

Pramusaji atau waiter dapat diartikan sebagai seseoarang yang melayani dan menyajikan makanan dan minuman di dalam sebuah restoran dan bar. Pramusaji adalah karyawan restoran yang menunggu kedatangan tamu, menyabut dengan ramah, sopan, dan akrab, mengantarkan tamu ke tempat duduk, menarikkan kursi saat tamu mau duduk, memberikan menu, mengambil dan menuliskan pesanan, meneruskannya ke dapur, mengambil makanan dan minuman serta menyajikannya kepada tamu, mengangkat alat-alat yang kotor, memberikan rekening, menyelesaikan pembayaran, serta menutup meja makan selengkap dan serapi mungkin untuk tamu berikutnya (Atmodjo dan Fauziah, 2016).

Pramusaji atau waiter ialah sesorang yang meyajikan makanan dan minuman di dalam sebuah restoran atau bar. Pramusaji merupakan karyawan/ karyawati di dalam sebuah restoran yang bertugas menunggu tamu, membuat tamu merasa mendapat sambutan dengan baik dan nyaman, mengambil pesanan makanan dan minuman serta menyajikannya, juga membersihkan restoran dan lingkungannya serta mempersiapkan meja makan (table setting) untuk tamu berikutnya (Marsum, 2005:10).

Dari definisi di atas dapat ditarik kesimpulan bahwa pramusaji adalah seseorang yang bertugas untuk melayani tamu dalam hal penyajian makanan dan minuman di sebuah restooran atau bar dari tamu datang hingga tamu meninggalkan restoran atau bar.

\section{Hubungan Pelatihan dengan Keterampilan Pramusaji}

Pelatihan dapat meningkatkan keterampilan pramusaji. Bentuk pelatihan agar pramusaji dapat meningkatkan keterampilannya dapat berupa materi pelatihan, pelatih dan metode pelatihan. Hal ini akan memberikan peningkatan yang tinggi bagi pramusaji ataupun tenaga kerja dalam mengemban tugas yang diberikan (Dharma, 1995).

Pelatihan yang dilakukan untuk pramusaji diharapkan dapat ditingkatkan keahlian, pengetahuan guna memperlancar tugas yang diberikan kepadanya dalam rangka mencapai tujuan perusahaan tersebut

\section{METODE PENELITIAN}

Jenis penelitian yang digunakan dalam penelitian ini adalah jenis penelitian explanatory research (penelitian penjelasan), yaitu suatu jenis penelitian untuk menguji hipotesis antara variabel yang satu dengan variabel yang lainnya. Menurut Hermawan (2009:20) explanatory research merupakan suatu penelitian yang menjelaskan hubungan kausal antara variabel-variabel melalui pengujian hipotesis. Penelitian ini menggunakan pendekatan kuantitatif. Subjek penelitian ini adalah karyawan pramusaji di Hotel Swiss-Belinn Malang dengan jumlah subjek 15 orang. Sampel yang digunakan dalam penelitian ini didapat dengan teknik pengambilan sampel (teknik sampling) Nonprobability Sampling dengan Sampling Jenuh. Peneliti menggunakan teknik sampling ini karena jumlah populasi sebanyak 15 orang. Sampling Jenuh yaitu teknik penentuan sampel bila semua anggota populasi digunakan sebagai sampel. Hal ini sering dilakukan bila jumlah populasi relatif kecil, kurang dari 30 orang (Sugiyono, 2016:85). Intrumen yang digunakan dalam pengambilan data ialah angket, wawancara, dan dokumentasi. Analisis data dalam penelitian ini menggunakan analisis deskriptif yang berisi distribusi item dari masing-masing variabel, kemudian menggunakan analisis regresi linier berganda untuk mengetahui besarnya pengaruh variabel pelatihan $(\mathrm{X})$ terhadap variabel keterampilan pramusaji (Y).

Indikator untuk Variabel pelatihan (X1) mengadopsi indikator pengukuran dari Mangkunegara (2014). Sedangkan variabel keterampilan pramusaji (Y) diukur dengan menggunakan indikator dari Atmodjo dan Fauziah (2016).

\section{HASIL DAN PEMBAHASAN}

\section{Profil Responden}

Total sebanyak 3 orang atau $20 \%$ berjenis kelamin laki-laki, sedangkan responden berjenis kelamin perempuan sebanyak 12 orang (80\%). Diketahui bahwa sebanyak 7 orang atau sekitar $46,7 \%$ dari responden berusia 19 tahun atau kurang dari 19 tahun, sebanyak 3 orang atau sekitar 20\% dari responden berusia 20 tahun, dan sisanya sebanyak 5 orang atau sekitar $33,3 \%$ berusia 21 tahun atau lebih 
Tabel 1. Rekapitulasi Hasil Uji Regresi Linier Berganda

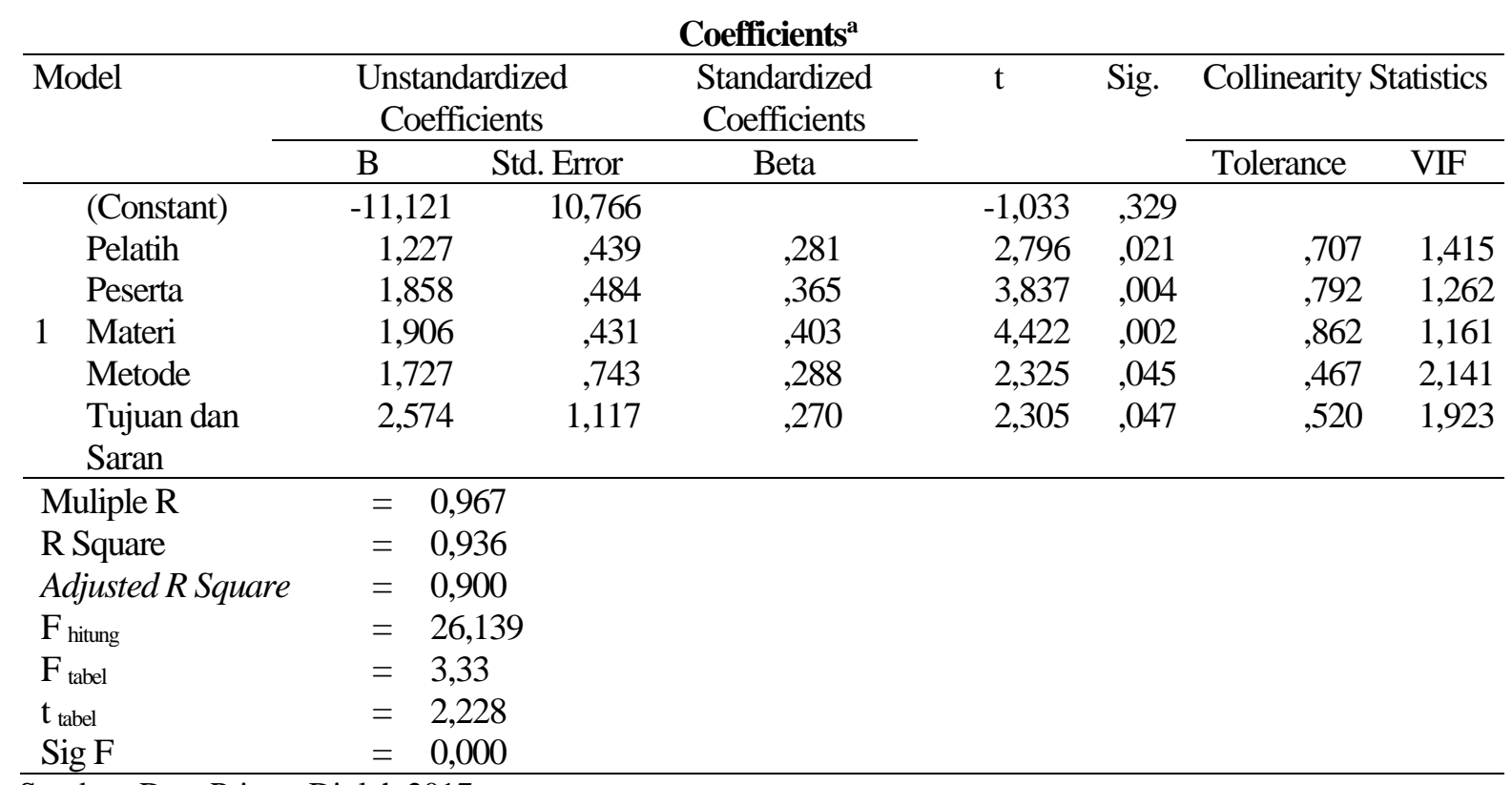

Sumber: Data Primer Diolah 2017

dari 21 tahun. karyawan bagian pramusaji di Hotel Swiss-Belinn Malang berlatar belakang pendidikan SMA sebanyak 7 orang $(46,7 \%), 6$ orang $(40 \%)$ berasal dari diploma, dan sisanya yaitu 2 orang $(13,3 \%)$ berpendidikan strata satu (S1). responden dengan masa kerja 1-6 bulan sebanyak 8 orang atau sekitar 53,3\%, kemudian 6 orang atau sekitar $40 \%$ mempunyai masa kerja 6-12 bulan, dan sisanya 1 orang atau sekitar $6,7 \%$ dengan masa kerja lebih dari 1 tahun.

Dalam penelitian ini uji hipotesis menggunakan regresi berganda dimana diuji secara empirik untuk mencari hubungan fungsional dua atau lebih variabel bebas dengan variabel terikat, atau untuk meramalkan dua variabel bebas atau lebih terhadap variabel terikat. Hasil penelitian ini adalah terdapat pengaruh signifikan antara Pelatih/Instruktur Pelatihan (X1), Peserta Pelatihan (X2), Materi Pelatihan (X3), Metode Pelatihan (X4), Tujuan dan Sasaran (X5) terhadap Keterampilan Pramusaji (Y). Hasil uji regresi linier berganda dalam penelitian ini dapat dilihat dalam tabel 1 .

Dari Tabel 1 dapat diinterpretasikan sebagai berikut:

1. Nilai $F_{\text {hitung }}$ menunjukkan nilai sebesar 26,139 (signifikansi F= 0,000). jadi Sig F < 5\% ( $0,000<$ $0,05)$, artinya bahwa secara bersama-sama variabel Pelatih/Instruktur Pelatihan (X1), Peserta Pelatihan (X2), Materi Pelatihan (X3), Metode Pelatihan (X4), Tujuan dan Sasaran (X5) berpengaruh signifikan terhadap variabel Y.

2. Nilai Adjusted $\mathrm{R}$ Square menunjukkan nilai sebesar 0,900 atau $90 \%$. Artinya bahwa variabel Y dipengaruhi sebesar $90 \%$ oleh Pelatih/Instruktur
Pelatihan (X1), Peserta Pelatihan (X2), Materi Pelatihan (X3), Metode Pelatihan (X4), Tujuan dan Sasaran (X5) sedangkan sisanya $10 \%$ dipengaruhi oleh variabel lain di luar lima variabel bebas yang diteliti.

3. Persamaan regresi

$\mathrm{Y}=-11,121+1,227 \mathrm{X}_{1}+1,858 \mathrm{X}_{2}+1,906 \mathrm{X}_{3}+$ $1,727 \mathrm{X}_{4}+2,574 \mathrm{X}_{5}$

4. Dari nilai thitung menunjukkan bahwa:

a. Variabel Pelatih/Instruktur Pelatihan $\left(\mathrm{X}_{1}\right)$ nilai t hitung sebesar 2,796 dengan probabilitas sebesar 0,021 . karena sig $\mathrm{t}<5 \%(0,001<0,05)$, maka secara parsial variabel Pelatih/Instruktur Pelatihan $\left(\mathrm{X}_{1}\right)$ berpengaruh signifikan terhadap Keterampilan Pramusaji (Y).

b. Variabel Peserta Pelatihan $\left(\mathrm{X}_{2}\right)$ nilai $\mathrm{t}$ hitung sebesar 3,837 dengan probabilitas 0,004. karena sig $\mathrm{t}<5 \%(0,009<0,05)$, maka secara parsial variabel Peserta Pelatihan $\left(\mathrm{X}_{2}\right)$ berpengaruh signifikan terhadap variabel Keterampilan Pramusaji (Y).

c. Variabel Materi Pelatihan $\left(\mathrm{X}_{3}\right)$ nilai t hitung sebesar 4,422 dengan probabilitas 0,002. karena sig t $<5 \%(0,009<0,05)$, maka secara parsial variabel Materi Pelatihan $\left(\mathrm{X}_{3}\right)$ berpengaruh signifikan terhadap variabel Keterampilan Pramusaji (Y).

d. Variabel Metode Pelatihan $\left(\mathrm{X}_{4}\right)$ nilai $\mathrm{t}$ hitung sebesar 2,325 dengan probabilitas 0,045. karena sig $\mathrm{t}<5 \%(0,009<0,05)$, maka secara parsial variabel Metode Pelatihan $\left(\mathrm{X}_{4}\right)$ berpengaruh signifikan terhadap variabel Keterampilan Pramusaji (Y). 
e. Variabel Tujuan dan Sasaran $\left(\mathrm{X}_{5}\right)$ nilai $\mathrm{t}_{\text {hitung }}$ sebesar 2,305 dengan probabilitas 0,047 . karena sig $\mathrm{t}<5 \%(0,009<0,05)$, maka secara parsial variabel Tujuan dan Sasaran $\left(\mathrm{X}_{5}\right)$ berpengaruh signifikan terhadap variabel Keterampilan Pramusaji (Y).

5. Berdasarkan Beta dari masing-masing variabel yaitu variabel Pelatih/Instruktur Pelatihan $\left(\mathrm{X}_{1}\right)$ sebesar 0,281, variabel Peserta Pelatihan $\left(\mathrm{X}_{2}\right)$ sebesar 0,365, Materi Pelatihan $\left(\mathrm{X}_{3}\right)$ sebesar 0,403 , Metode Pelatihan $\left(\mathrm{X}_{4}\right)$ sebesar 0,288 , serta Tujuan dan Sasaran $\left(\mathrm{X}_{5}\right)$ sebesar 0,270 maka dapat disimpulkan bahwa variabel Materi Pelatihan $\left(X_{3}\right)$ adalah variabel yang paling dominan pengaruhnya terhadap Keterampilan Pramusaji (Y).

\section{Pengaruh Pelatih Pelatihan terhadap Keteram- pilan Pramusaji}

Berdasarkan hasil penelitian, variabel Pelatih Pelatihan (X1) berpengaruh terhadap variabel Keterampilan Pramusaji (Y). Hal ini diperkuat oleh teori yang dikemukakan Mangkunegara (2006:46) bahwa pelatih umumnya berorientasi pada peningkatan skill, maka para pelatih yang dipilih untuk memberikan materi pelatihan harus benar-benar memiliki kualifikasi yang memadai sesuai bidangnya, personal dan kompeten, selain itu pendidikan intruktur pun harus benar-benar baik untuk melakukan pelatihan.

\section{Pengaruh Peserta Pelatihan terhadap Keteram- pilan Pramusaji}

Berdasarkan hasil penelitian, variabel Peserta Pelatihan (X2) berpengaruh terhadap variabel Keterampilan Pramusaji (Y). Hal ini juga diperkuat oleh teori yang dikemukakan oleh Mangkunegara (2014) yang menyatakan bahwa, peserta pelatihan tentunya harus diseleksi berdasarkan persyaratanpersyaratan tertentu dan kualifikasi yang sesuai. Peserta pelatihan yang tidak sesuai dengan kriteria yang disyaratkan oleh kegiatan pelatihan dapat menyebabkan terjadinya penggunaan alokasi waktu, dana, dan energi yang berlebihan bahkan sia-sia dalam kegiatan pelatihan dan pengembangan sumber daya manusia.

\section{Pengaruh Materi Pelatihan terhadap Keteram- pilan Pramusaji}

Berdasarkan hasil penelitian, variabel Materi Pelatihan (X3) berpengaruh terhadap variabel Keterampilan Pramusaji (Y). Hal ini juga diperkuat oleh teori yang dikemukakan oleh Handoko
(2003:109) yang menyatakan bahwa, isi program ditentukan oleh identifikasi kebutuhan-kebutuhan dan sasaran-sasaran latihan. Program mungkin berupaya untuk mengajarkan berbagai keterampilan tertentu, menyampaikan pengetahuan yang dibutuhkan atau mengubah sikap. Program hendaknya memenuhi kebutuhan-kebutuhan organisasi dan peserta. Pelaksanaan program pelatihan hendaknya menyusun dan menyampaikan materi pelatihan dengan jelas, agar sasaran dan tujuan dari perusahaan dapat dicapai dengan baik. Ini akan berimbas pada tujuan dari pelatihan itu sendiri yaitu meningkatkan kemampuan kerja.

\section{Pengaruh Metode Pelatihan terhadap Keteram- pilan Pramusaji}

Berdasarkan hasil penelitian, variabel Metode Pelatihan (X4) berpengaruh terhadap variabel Keterampilan Pramusaji (Y). Hal ini juga diperkuat oleh teori yang dikemukakan Mangkunegara (2009:63) bahwa hampir 90 persen dari pengetahuan pekerjaan diperoleh melalui metode on the job training. Pengetahuan disini termasuk dalam item variabel Keterampilan Pramusaji (Y), dimana apabila metode pelatihan yang digunakan sudah benar, maka sasaran dari peningkatan kemampuan kerja juga akan berpengaruh besar.

\section{Pengaruh Tujuan dan Sasaran Pelatihan terhadap Keterampilan Pramusaji}

Berdasarkan hasil penelitian, variabel Tujuan dan Sasaran (X5) berpengaruh terhadap variabel Keterampilan Pramusaji (Y). Hal ini juga diperkuat oleh teori yang dikemukakan oleh Jackson (2010:28) yang menyatakan bahwa, program pembelajaran atau pengembangan harus memiliki isi yang sama dengan sasaran pembelajaran. Sasaran pembelajaran yang umum biasanya mencakup peningkatan kognitif, mengembangkan keterampilan pegawai, mengifluensi renspons afektif, dan mendorong perilaku.

\section{SIMPULAN DAN SARAN}

\section{Kesimpulan}

Berdasarkan hasil penelitian yang telah dilakukan di Hotel Swiss-Belinn Malang, maka dapat diambil kesimpulan, yaitu: (a) Variabel pelatihan yang meliputi Pelatih Pelatihan (X1), Peserta Pelatihan (X2), Materi Pelatihan (X3), Metode Pelatihan (X4), serta Tujuan dan Sasaran Pelatihan (X5) mempunyai pengaruh yang signifikan secara simultan terhadap Keterampilan Pramusaji (Y). (b) Variabel Pelatih/Instruktur Pelatihan (X1), Peserta Pelatihan (X2), Materi Pelatihan (X3), 
Metode Pelatihan (X4), Tujuan dan Sasaran Pelatihan (X5) mempunyai pengaruh signifikan secara parsial terhadap variabel Keterampilan Pramusaji (Y). (c) Variabel Materi Pelatihan (X3) mempunyai pengaruh yang paling kuat dibandingkan dengan variabel yang lainnya terhadap Keterampilan Pramusaji (Y).

\section{Saran}

Terdapat beberapa saran yang diharapkan dapat bermanfaat bagi perusahaan maupun bagi pihak-pihak lain. Adapun saran yang diberikan adalah Perusahaan diharapkan mampu meningkatkan kualitas materi pelatihan, karena materi pelatihan merupakan faktor utama penunjang keberhasilan program pelatihan yang dilaksanakan. Perusahaan diharapkan mampu memonitor pelaksanaan pelatihan itu sendiri, dimana perlu diamati dengan baik performance dan keterlibatan karyawan di dalam pelaksanaan pelatihan. Mengkomunikasikan hasil penilaian kinerja pada saat pelatihan secara terbuka kepada masing-masing karyawan agar karyawan dapat memperbaiki kinerjanya, bersungguh-sungguh dalam mengikuti pelatihan, dan mengimplementasikan materi pelatihan dalam tugasnya hari-hari. Bagi pembaca atau pimpinan dari perusahaan lain, hasil penelitian ini dapat dijadikan pertimbangan dala membuat kebijakan terhadap pengembangan karyawannya dengan pelaksanaan pelatihan.

\section{DAFTAR REFERENSI}

Admin. 2016. Kota Malang Dalam Angka 2016. Katalog BPS 1102001.3573. https://malangkota. bps.go.id/index.php/publikasi/82. Diakses pada tanggal 20 Maret 2017 pada jam 19.37WIB.
Atmodjo, Marsum Widjojo dan Siti Fauziah. (2016). Profesional Waiter. Yogyakarta: CV. Andi Offset.

Dessler, Gary. 2016. Manajemen Sumber Daya Manusia. Jakarta: Salemba Empat

Handoko, Hai T. 2003. Manajemen Personalia dan Sumber Daya Manusia. Cet. 18. Yogyakarta. BPEE.

Iverson. (2001). Memahami Keterampilan Pribadi. Bandung: CV. Pustaka

Jackson, Schuler, Werner. 2010. Pengelolaan Sumber Daya Manusia. Jakarta: Salemba Empat.

Larasati, Sri. 2016. Excellent Hotel Operation. Yogyakarta: Ekuilibria

Mangkunegara, Anwar Prabu. 2006. Perencanaan Dan Pengembangan Manajemen Sumber Daya Manusia. Jakarta: PT Refika Aditama.

Mangkunegara, Anwar Prabu. 2009. Manajemen Sumber Daya Manusia Perusahaan. Edisi Kesembilan. Bandung. PT Remaja Rosdakarya.

Mangkunegara, Anwar Prabu. 2014. Manajemen Sumber Daya Manusia Perusahaan. Bandung: PT. Remaja Rosdakarya.

Marsum, A.W. 2005. Restoran dan Segala Permasalahannya, Edisi IV. Yogyakarta: Andi.

Punarya, I Gusti Ketut. 2016. Manajemen Sumber Daya Manusia. Yogyakarta: Penerbit Andi

Sinambela, Lijan Poltak. 2016. Manajemen Sumber Daya Manusia. Jakarta: PT. Bumi Aksara

Soemarjadi, dkk. 2001. Pendidikan Ketrampilan. PT Gramedia PustakaUtama: Jakarta.

Utama, I.G.B.R. 2016. Pengantar Industri Pariwisata Tantangan dan Peluang Bisnis Kreatif. Yogyakartya: Deepublish. 